\author{
하수처리장의 포기조 최적 DO 농도 산정 및 공기송풍량 자동제어를 \\ 통한 에너지 절감 효과 도출 \\ 김민한 · 지승희 · 장정희 ${ }^{* \dagger}$ \\ (주팬지아이십일, ${ }^{*}$ 고등기술연구원 \\ (2014년 4월21일 접수, 2014년 6월 3일 수정, 2014년 6월 5일 채택)
}

\title{
A Study on Energy Saving Effect from Automatic Control of Air Flowrate and Estimation of Optimal DO Concentration in Oxic Reactor of Wastewater Treatment Plant
}

\author{
Kim Min Han $\cdot$ Ji Seung Hee $\cdot$ Jang Jung Hee ${ }^{* \dagger}$ \\ PANGAEA21, Ltd, "Institute for advanced engineering \\ (Received 21 April 2014, Revised 3 June 2014, Accepted 5 June 2014) \\ 요약 \\ 생물학적 하수처리공정에서 안정적인 방류수질 확보와 처리 비용을 적게 하는 것은 매우 중요하다. \\ 하지만 유입수 유량 및 성분 농도의 변화와 미생물의 비선형적인 동특성, 기타 환경 요인에 의해서 \\ 최적의 운전 제어를 하기가 쉽지 않기 때문에, 기존의 하수처리장에서는 필요한 양 이상의 폭기 및 \\ 화학물질을 과량 주입하는 방법 등을 사용하였다. 본 연구에서는 포기조에서 미생물에 필요한 용존산 \\ 소농도를 유지함과 동시에 과폭기로 인한 전력 비용을 감소할 수 있는 최적 제어 방법을 제안하였다. \\ 최적 제어를 위하여 실시간 미생물 호흡률 측정기(Oxygen uptake rate, OUR)을 이용하여 측정하였고, \\ 실시간 호흡률 측정값을 바탕으로 현재 미생물에 필요한 최적 DO 농도를 제안하였으며, 이에 따라 \\ 공기송풍기가 자동제어될 수 있도록 구성하였다. 최적 제어 방법을 통하여 하수처리장 포기조의 공기
} 송풍량에 소요되는 전력비용을 절감할 수 있었다.

주요어 : 하수처리장, DO 최적화, 공기 송풍량, 에너지 절감

Abstract - It is important to keep stable effluent water quality and minimize operation cost in biological wastewater treatment plant. However, the optimal operation is difficult because of the change of influent flow rate and concentrations, the nonlinear dynamics of microbiology growth rate and other environmental factors. Therefore, many wastewater treatment plants are operated for much more redundant oxygen or chemical dosing than the necessary. In this study, the optimal control scheme for dissolved oxygen (DO) is suggested to prevent over-aeration and the reduction of the electric cost in plant operation while maintaining the dissolved oxygen (DO) concentration for the metabolism of microorganisms in oxic reactor. For optimal control, The oxygen uptake rate (OUR) is realtime measured for the identification of influent characterization and the identification of microorganisms' oxygen requirement in oxic reactor. Optimal DO seT-Point needed for the microorganism is suggested based on real time measurement of oxygen uptake of microorganism and the control of air blower. Therefore, both stable effluent quality and minimization of electric cost are satisfied with a suggested optimal

\footnotetext{
${ }^{\dagger}$ To whom corresponding should be addressed.

Institute for advanced engineering, 175-28, 51 Goan-ri,

Baegam-myeon, Cheoin-gu, Yongin-si, Gyeonggi-do, 463-400 Korea.

Tel : 031-330-7410 E-mail : azazjh@gmail.com
} 
setpoint decision system by providing the necessary oxygen supply requirement to the microorganisms coping with the variations of influent loading.

Key words : wastewater treatment plant, DO optimization, Air flowrate control, Energy saving

\section{1. 서 론}

최근 수자원에 대한 관심이 높아지고, 하수처리장 의 방류수 수질기준의 규제가 강화되면서, 하수처리 장의 방류수질을 안정적으로 유지시킴과 동시에 처리 비용을 절감시키기 위하여 공정의 고도화 및 최적 운 전의 필요성이 대두되고 있다. 하수처리공정이 고도 화되면서 생물학적 처리공정이 도입되어 유입원수의 오염물질을 제거한다. 특히, 생물반응조에서 미생물 이 오염물질 증 유기물을 제거하거나 질소를 변환하 기 위해서는 산소가 반드시 필요하며, 일반적으로 산 소는 공기송풍기를 통해 공기를 넣어줌으로써 생물반 응조로 유입된다.

미생물이 유기물 산화와 질산화를 수행하기 위해 서는 포기조 내 용존산소(Dissolved Oxygen, DO)가 적절한 농도로 유지되어야 한다. 만약 용존산소농도 가 미생물이 성장하기에 부족한 경우 사상균이 우점 하게 되어 활성슬러지의 침전성이 나빠져 방류수 수 질이 악화되는 요인이 되며, 용존산소가 필요 이상으 로 존재할 경우 처리수 수질의 개선 효과는 거의 없 으나 과량의 용존산소는 미생물에 의해 사용되지 않 고 공기 중으로 빠져나가게 된다. 그러므로, 미생물이 필요로 하는 용존산소농도를 유지시키며, 필요 이상 의 공기를 주입하여 폐기되는 용존산소를 줄이는 등 처리능력 향상 및 적정 공기공급에 의한 운전비용을 감소할 필요가 있다[1].

특히 하수처리장 전체 운영비용 중 전력비가 약 $40 \%$ 를 차지하며, 전력비용 중 송풍기에 의한 전력비 용이 적지 않은 부분을 차지한다. 그렇기 때문에 송 풍기 가동에 의한 전력비용을 절감함으로써 하수처리 공정의 전체 운영비용을 상당부분 절감할 수 있다.

1980년대 이후 International Water Association(IWA) 산하 task 그룹에서 활성슬러지 공 정에 대한 수학적 모델 (Activated sludge model, $\mathrm{ASM}$ )을 개발함으로써 모델링 기법을 사용한 하수처 리장의 공정 모사 등에 대한 연구가 활발히 진행되었 다[2]. 호흡률 측정법 등을 이용하여 활성슬러지모델 에서 유입하수의 성상 분석과 미생물의 동특성을 파
악하여 공정에서 발생하는 여러 상황에 대한 모사를 수행하였다[3]. 하수의 특성 및 환경 요인이 다르기 때문에 활성슬러지 모델을 적용하기 위해서는 특성별 유입수 성상분석 또는 모델 보정 등이 선행되어야 한 다. 국내에서도 호흡률 측정법을 이용하여 유입수의 성상분석과 모델 동특성을 파악, 매개변수 추정, 공정 최적화 등에 대한 연구가 진행되었다[4-6].

본 연구에서는 미생물의 산화반응에 필요한 포기 조 내 최적 용존산소농도를 산정하여 그에 따른 송풍 량을 제어하고자 한다. 생물학적 하수처리공정에서의 미생물 동특성은 하수의 성분, 발생 및 배제 등 다양 한 조건에 영향을 받기 때문에 지역 및 환경에 따라 매우 상이하게 보고되고 있다[7,8]. 또한, 생물학적 처리에 있어서 산소는 미생물의 호흡과 기질의 분해 에 직접적으로 관여하고 있기 때문에 호흡률 측정법 은 미생물과 하수의 특성을 밝히는데 좋은 방법으로 알려져 있다[5]. 따라서 본 연구에서는 호흡률 측정법 을 사용하여 미생물 동특성을 파악하여 최적 용존산 소농도를 산정함으로써 효율적이고 경제적인 하수처 리공정의 운전조건을 제시하고자 한다.

\section{2. 연구 방법}

본 연구에 사용된 호흡률 측정을 통한 최적 DO 산 정 및 송풍량 제어 프로세스는 Fig.1 에 나타난 흐름도 와 같다. 포기조의 하수를 자동 샘플링하여 미생물의 호흡률(oxygen uptake rate, OUR)을 측정하고, OUR 을 바탕으로 최적 DO 농도를 산정 및 검증하였다. 방 류수의 수질기준을 만족시키기 위해 방류 COD와 T-N 농도를 운영자가 설정한 기준 농도값과 비교하여 기준 농도값 이하일 경우 방류수 수질을 만족하는 것으로 판단되어 최적 $\mathrm{DO}$ 농도값을 송풍기로 전달하여 $\mathrm{DO}$ 제어를 수행하였다. 방류 $\mathrm{COD}$ 와 T-N 농도가 기준 농 도값보다 높을 경우에는, 산정된 $\mathrm{DO}$ 농도를 보정하여 최적 $\mathrm{DO}$ 농도를 재 산정함으로써 실제 가동중인 테스 트베드에서의 시운전 안정성을 향상시켰다. 이렇게 산 정된 최적 DO 농도는 송풍기로 전달하여 송풍기 자체 에서는 최적 $\mathrm{DO}$ 농도 이하로 운전되도록 한다. 


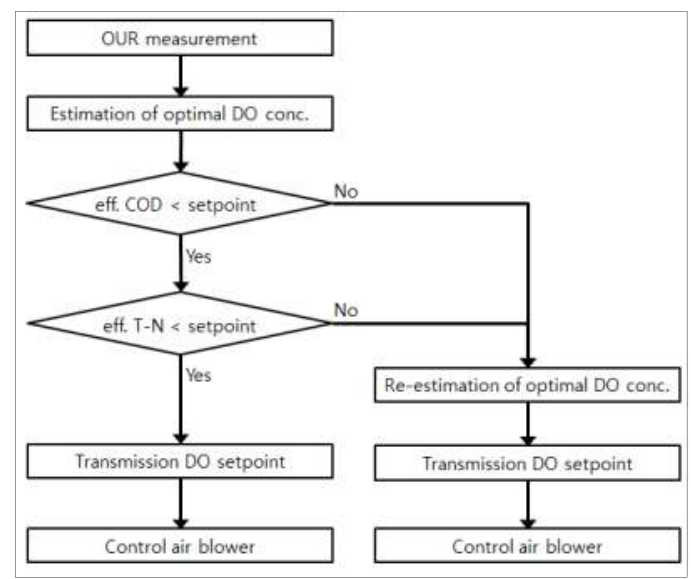

Fig. 1. The flowchart of the proposed DO optimal set-point decision and air blower control.

\section{2-1 미생물 호흡률(OUR) 측정}

미생물이 기질(Substrate)을 분해할 때 소모시키는 산소량은 일반적으로 단위시간당 소모되는 산소량인 호흡률 또는 산소섭취속도(OUR, Oxygen Uptake Rate)로 측정된다. 호흡률은 포기조 내의 미생물의 대사활동을 직접 측정하는 상태변수로써, 미생물량의 증가 및 기질 제거와 직접적인 연관이 있으므로 이를 측정하는 것은 활성슬러지 공정의 운전을 위해서 유 용한 기술이다[9]. 흔히, 포기조로 유입되는 생물학적 분해 가능물질의 농도가 높을수록 포기조 내 미생물 의 활성이 높을수록 OUR은 높은 값을 나타낸다.

미생물의 호흡률을 측정하는 방법에는 대표적으로 두 가지가 있다. 첫째는 미생물이 존재하는 액상에서 의 산소농도 감소율을 측정하는 것으로, $\mathrm{DO}$ 센서를 사용하여 액상의 용존산소 농도의 변화를 측정한다. 포기조에서의 하수를 샘플링하여, 반응기에 넣고 일 정 시간 간격으로 액상의 DO 농도를 측정하면, 미생 물이 일정시간 간격으로 얼마만큼의 $\mathrm{DO}$ 를 소비하는 지 파악할 수 있다. 이 때, 미생물이 단위시간당 소비 하는 DO 농도값을 OUR로서 계산되며, 본 연구에서 사용한 방법도 이와 같다. 또 다른 방법으로는 미생 물이 존재하는 액상으로의 산소 전달률을 측정하는 것으로 기상의 산소 농도와 액상의 산소 농도가 평형 을 이룬다는 가정 하에 기상의 산소농도의 변화를 측 정하는 것이다. 이 또한, 일정시간 간격으로 미생물이 소비하는 DO 농도를 산출함으로써 OUR을 계산한다 [10-12].

본 연구에서는 액상에서의 산소농도 감소율을 측

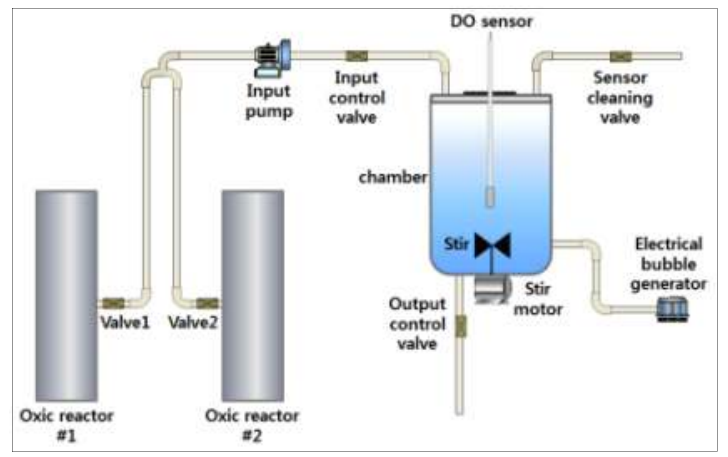

Fig. 2. The scheme of OUR measurement in WWTP.

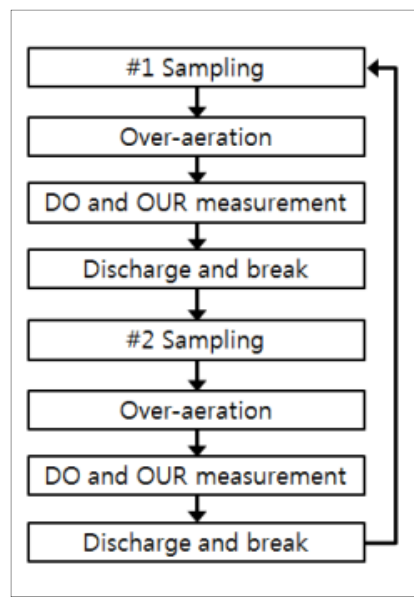

Fig. 3. The process of respirometry measurement.

정하는 방법으로써, Fig.2와 같은 구성과 Fig.3과 같 은 절차에 의해 OUR을 측정하였다. 첫 단계에서는 포기조 1계열에 설치된 설치밸브와 유입펌프가 가동 되며 반응조 유입조절밸브가 열리면서 하수가 5 분여 간 전량 반응기에 채운다. 5 분여간의 시간동안 이전 과정에서 배관에 남아있던 공기 및 하수를 배출하고, 순수 1 계열의 하수만 반응기에 유입되도록 한다. 다 음으로 1 분동안 반응기 내 전기기포발생기 및 산기관 에 의해 미세한 산소가 연속적으로 공급되어 하수 내 용존산소농도를 증가시키며, 교반모터 작동에 의해 하수의 완전혼합을 유지한다. 수질계측센서로 $\mathrm{DO}$ 를 측정하며, 본 연구에서는 1 분 간격으로 약 20 분간 $\mathrm{DO}$ 농도를 측정하도록 설정하였다. 측정이 완료되면 반응기 하부에 연결되어 있는 배출배관의 전동구동밸 브가 열리면서 3 분동안 공압식으로 센서를 세척하고, 반응기에 있는 하수는 모두 배출이 되고 1 분의 휴지 기를 거친 후, 포기조 2 계열의 샘플밸브가 열리면서 앞의 기작이 연속적으로 수행된다[13]. 이렇게 2계열 
의 측정을 1 cycle로 정하고, 1 cycle은 매 시간마다 연속적으로 측정된다. Fig.4는 본 연구에서 사용된 호 흡률 측정기이며, 하수의 유입과 유출 라인, 반응기, $\mathrm{DO}$ 센서, 기포발생기와 유입 라인을 확인할 수 있다.

\section{2-2 미생물 호흡률에 기반한 산소호흡률과 최적 DO 농도 산정}

포기조 내 미생물이 전자수용체로 산소를 사용함 으로써 유기물 산화와 질산화가 진행된다. 전자수용 체로 사용되는 적당한 양의 산소가 지속적으로 미생 물에게 공급되어야 하는데, 이 때의 필요한 산소량을 측정하기 위하여 호흡률측정법을 사용한다. 반응기에 유입하수 주입 후, 과폭기를 하여 시간당 소비되는 $\mathrm{DO}$ 농도 추이를 통한 산소섭취속도를 측정하는 이유 는 미생물에게 필요한 적정 용존산소를 산정하기 위 함이며, 여기에서 측정된 최적 $\mathrm{DO}$ 농도를 유지하게 됨으로써 안정적이고 효율적인 포기조 운영이 가능하 게 된다.

OUR 측정 과정 중 유입하수를 반응기 안에 채우 고 과폭기하여 $\mathrm{DO}$ 농도를 최대로 높인 후 폭기를 중 단하면 DO 농도가 감소하는데, 이를 통해 미생물이 산소를 소비한다는 것을 확인 할 수 있다. 그에 따라 단위시간당 OUR이 계산되며, 이는 다음 식(1)에 의 해서 계산된다.

$$
O U R=\frac{D O_{t-1}-D O_{t}}{\Delta t}
$$

Fig.5는 일반적인 미생물의 호흡률 측정 결과 그래 프를 나타내며, 그래프를 통해 최적 DO 농도를 산정 할 수 있다. 기포발생기를 통해 공기를 최대한 주입 함으로써 하수 내 산소농도는 과포화상태가 된다. 그 후, 미생물이 유기물 산화 및 질산화를 위해 산소를 사용하게 되고, $\mathrm{DO}$ 농도는 감소한다. $\mathrm{DO}$ 농도가 감 소하면서 미생물이 더 이상 유기물 산화 및 질산화를 할 수 없을 때에 DO 농도는 일정해 진다. 호흡률 곡 선을 보면, DO 농도가 높을 때에는 미생물의 활성도 가 증가하여 그에 따라 산소호흡률이 높다. DO 농도 가 감소하면서 미생물의 호흡률이 서서히 낮아지는 것을 확인할 수 있고, DO 농도가 일정해 지면서 호 흡률은 0 으로 감소한다. $\mathrm{DO}$ 농도가 일정하다는 것은 이미 미생물이 산소를 사용할 필요가 없다는 것을 의

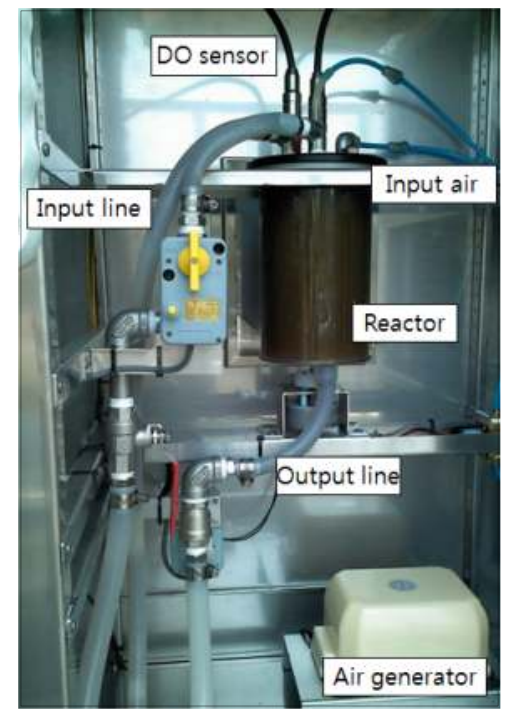

Fig. 4. The respirometry used for this study.

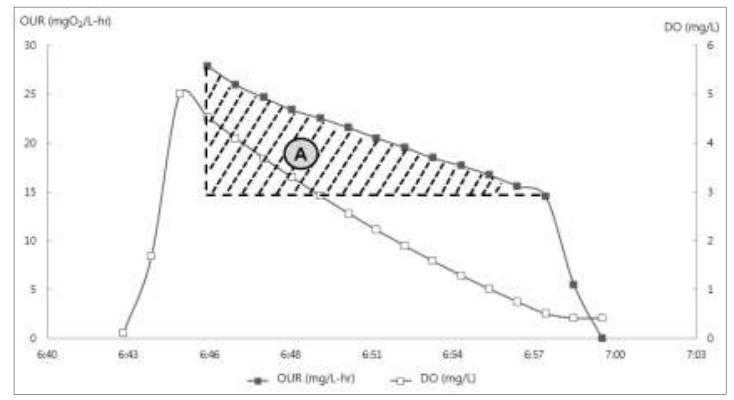

Fig. 5. The measurement results of (a) DO and (b) OUR.

미하며, 그 직전까지의 호흡률, 즉 호흡률 곡선이 급 격히 감소하기 직전까지가 미생물에게 필요한 최대 $\mathrm{DO}$ 농도가 될 수 있고, 최대 $\mathrm{DO}$ 농도 이상으로 공 기가 주입되어도 미생물은 더 이상 산소를 사용하지 않는다. 이 때의 (A) 면적을 통해 최적 DO 농도를 계산할 수 있으며, 면적과 최적 DO 농도는 비례한다. (A) 면적은 다음 식과 같이 지점에서의 중간높이를 구한 후, 사각형 넓이의 합으로 계산한다.

$$
\begin{aligned}
& A=\left(\Delta t \times \frac{y_{1}+y_{2}}{2}+\Delta t \times \frac{y_{2}+y_{3}}{2}+\cdots\right. \\
& \left.+\Delta t \times \frac{y_{n-1}+y_{n}}{2}\right)-\left((n-1) \times \Delta t \times y_{n}\right)
\end{aligned}
$$

2-3 방류수질 농도 검증을 통한 최적 $\mathrm{DO}$ 농도 산정 


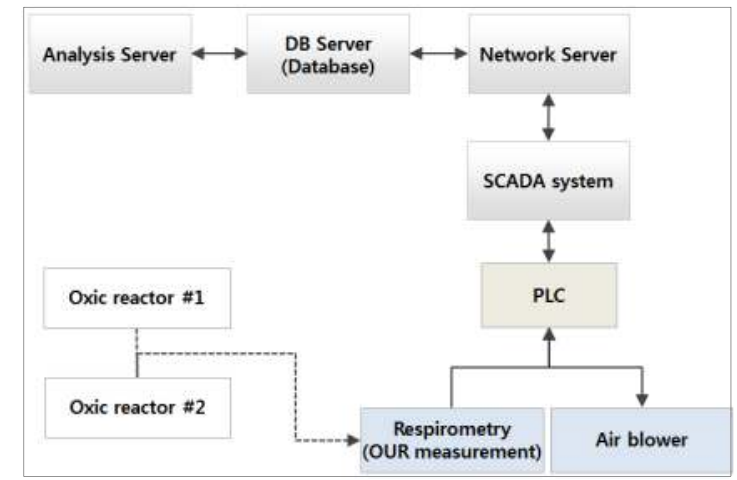

Fig. 6. The system configuration for this study.

생물학적처리 공정 특성으로 인해 하수처리 공정 의 미생물 기작이나 하수 오염물질 제거에 영향을 주 는 요인으로 온도, $\mathrm{pH}$, 유입부하 등 여러 가지가 있 지만, 공정의 비선형성으로 인하여 이러한 요인들의 최적 조건을 제시하는 데에는 한계가 있다 $[9,14]$. 그 결과 현재까지의 하수처리장의 운전은 경험이 풍부한 전문가의 판단에 의해서 대부분 수행되고 있으며, 결 국 최적 관리는 한계를 가질 수밖에 없었다 $[14,15]$. 본 연구에서는 실제 가동중인 $\mathrm{D}$ 하수처리장을 테스 트베드로 하여 실운전을 수행하였고, 실운전을 수행 함에 있어 안정성을 강화하기 위하여, 방류수질의 상 태에 따라 산정된 DO 농도의 적용 여부를 결정하고 보정함으로써, 공정의 신뢰성 및 안정성을 높일 수 있도록 하였다.

대부분의 하수처리장에는 원격수질감시체계 (Tele-Monitoring System, TMS)가 구축되어 TSS, COD, T-N, T-P 농도의 방류수질을 실시간으로 측정 및 모니터링하고 있다. 이 중, 포기조 DO 농도에 의 해 영향을 받을 수 있는 방류 COD와 T-N 농도가 방 류수질 기준 또는 운영자가 임의로 지정한 농도보다 낮을 경우 정상으로 간주되어 이전단계에서 제시된 최적 DO 농도를 송풍기 제어시스템으로 전송하여 제 어 운전되도록 하였으며, 방류수 $\mathrm{COD}$ 와 T-N 농도가 기준 농도보다 높을 경우, 이는 비정상으로 간주되어 이전 단계에서 산정된 최적 DO 농도를 적용하지 않 고 $\mathrm{DO}$ 농도를 재산정하여 적용하였다.

방류수의 COD 및 T-N 항목 중, 어느 하나의 항목 이 기준 농도보다 높을 경우에는 이미 산정된 $\mathrm{DO}$ 농 도를 높여 산화반응이 더 많이 일어나도록 유도하였 다. 식 (3)과 같이 현재 방류수의 $\mathrm{COD}$ 농도(CODt) 와 $\mathrm{COD}$ 기준 농도(CODc)의 비가 방류수 $\mathrm{T}-\mathrm{N}$ 농도 (T-Nt)와 T-N 기준 농도(T-Nc)의 비 중 큰 값을 현
Table 1. Influent and effluent conditions in wastewater treatment plant.

\begin{tabular}{c|c|c|c}
\hline \multicolumn{2}{c|}{ Influent conditions } & \multicolumn{2}{c}{ Effluent conditions } \\
\hline \hline flow-rate & $4,000 \mathrm{~m} 3 / \mathrm{d}$ & \multicolumn{2}{|c}{-} \\
\hline BOD & $198.2 \mathrm{mg} / \mathrm{L}$ & BOD & $4.2 \mathrm{mg} / \mathrm{L}$ \\
\hline COD & $114.5 \mathrm{mg} / \mathrm{L}$ & COD & $10.2 \mathrm{mg} / \mathrm{L}$ \\
\hline SS & $196.4 \mathrm{mg} / \mathrm{L}$ & $\mathrm{SS}$ & $4.6 \mathrm{mg} / \mathrm{L}$ \\
\hline T-N & $59.673 \mathrm{mg} / \mathrm{L}$ & T-N & $10.075 \mathrm{mg} / \mathrm{L}$ \\
\hline T-P & $6.245 \mathrm{mg} / \mathrm{L}$ & T-P & $1.156 \mathrm{mg} / \mathrm{L}$ \\
\hline
\end{tabular}

재 $\mathrm{DO}$ 농도(DOt)에 곱한 후 안전계수(safety factor, s.f)를 적용하여 보정된 최적 $\mathrm{DO}$ 농도로 재산정하였.다.

$$
D O=\max \left[\frac{C O D_{t}}{C O D_{C}}, \frac{T N_{t}}{T N_{C}}\right] \times D O_{t} \times s . f
$$

여기에서 COD 및 T-N 의 기준 농도는 운영자가 방류수질 변동 범위를 고려하여 설정할 수 있으며, 일반적으로 방류수질기준의 $70 \sim 80 \%$ 로 사용할 것을 한다.

방류수질을 통해 최적 DO 농도를 재산정함으로써 호흡률 측정을 통한 최적 DO 농도 산정 결과를 실 처리장에 적용을 하더라도 혹시 모를 사고에 대비할 수 있고, 최종적으로는 하수처리장의 운영에 가장 중 요한 기준이 되는 방류수질기준을 만족시키는 안정적 인 방법을 제시하였다. 본 연구 내용은 호흡률 측정 의 기기 오류 및 문제점 발생시, 또는 공정 이상 및 급격한 유입 부하 등이 발생하였을 때에도 안정적인 방류수질을 제공하도록 최적 $\mathrm{DO}$ 농도 설정이 가능하 다.

\section{3. 연구 결과}

본 연구에서는 실제 가동 중인 하수처리장을 테스 트베드로 이용하였다. 테스트베드로 활용된 하수처리 장은 용량 $4,000 \mathrm{~m} 3 /$ 일 규모의 처리장으로, 음식물쓰 레기 산발효액을 이용한 하수처리고도처리 공법인 TEC-BNR 공법이 적용되었으며, 유입수 및 방류수 현황은 Table 1과 같다. 2013년 1월 2014년 3월 
Table 2. The results of the DO, effluent concentration, air flowrate and eletric energy.

\begin{tabular}{c|c|c|c|c|c|c|c}
\hline \multirow{2}{*}{ Contents } & \multirow{2}{*}{ unit } & \multicolumn{3}{|c|}{$2014.03 .01 . \sim 2014.03 .16$} & \multicolumn{3}{c}{$2014.03 .17 . \sim 2014.03 .31$} \\
\cline { 3 - 8 } & & Min. & Max. & Avg. & Min. & Max. & Avg. \\
\hline \hline$\# 1$ DO conc. & $\mathrm{mg} / \mathrm{L}$ & 0.86 & 7.30 & 4.10 & 1.04 & 5.55 & 2.21 \\
\hline$\# 2$ DO conc. & $\mathrm{mg} / \mathrm{L}$ & 0.50 & 6.24 & 3.01 & 1.01 & 4.13 & 2.14 \\
\hline \#2 Opt. DO conc. & $\mathrm{mg} / \mathrm{L}$ & - & - & - & 1.04 & 3.50 & 1.79 \\
\hline Eff. COD conc. & $\mathrm{mg} / \mathrm{L}$ & 4.9 & 15.1 & 13.4 & 12.2 & 15.4 & 13.7 \\
\hline Eff. T-N conc. & $\mathrm{mg} / \mathrm{L}$ & 5.74 & 78.26 & 17.10 & 15.59 & 77.69 & 16.9 \\
\hline Air flowrate & $\mathrm{m} 3 / \mathrm{hr}$ & 329 & 971 & 671 & 248 & 931 & 558 \\
\hline Eletric Energy & $\mathrm{KW}$ & 8.28 & 24.89 & 16.83 & 6.33 & 24.62 & 14.20 \\
\hline 2013 Air flowrate & $\mathrm{m} 3 / \mathrm{hr}$ & - & - & - & 510 & 1187 & 731 \\
\hline 2013 Eletric Energy & $\mathrm{KW}$ & - & - & - & 12.01 & 27.64 & 16.18 \\
\hline
\end{tabular}

의 13 개월동안 테스트베드에 호흡률 측정기를 설치 하여 시운전하였으며, 공기송풍량 최적화 시스템의 개발 완료 및 2014년 3월 17일에 시스템을 적용하여 송풍기 자동제어를 실시하였다. 이 시점을 중심으로 시운전 전/후 2주간, 2013년 동일시기의 데이터 비교 를 중심으로 결과를 정리하였다.

호흡률측정 장비는 포기조 1 계열과 2 계열에서 배 관을 연결하여 샘플링하여 분석하였고, 계열별로 하 수 샘플링 및 반응기 내 유입, 과폭기, 1 분 단위의 OUR 측정, 하수 유출 및 휴지 단계로 연속측정 하였 으며, 1,2 계열을 1 cycle(1시간)로 측정하였다.

Fig. 6.은 본 연구를 수행하기 위한 전체 공정을 나 타낸다. 포기조 1,2 계열에서 샘플링해 OUR 분석기 에서 호흡률을 측정하여 현장 PLC (Programmable Logic Control), 감시제어시스템, 통신서버를 통해 $\mathrm{DB}$ (Database) 서버에 저장된다. 분석서버에서 실시 간 호흡률 값을 가져와 분석하여 최적 DO 농도가 산 정되고, 이 DO 설정치를 최종적으로 송풍기로 보냄 으로써, 송풍기에서는 포기조의 DO 농도를 제안한 설정치로 유지되도록 송풍량을 제어한다. Database 프로그램은 MS-SQL을 사용하였고, 분석서버에서의 최적 $\mathrm{DO}$ 산정 시스템은 JAVA 기반으로 (주)팬지아 이십일에서 직접 개발하였다.

2014년 3월 17일 기점으로 시스템을 적용하였고, 시스템을 적용하기 이전과 이후 2 주간의 데이터 결과 는 Table 2 와 같다. 시스템 적용 이전의 1 계열과 2계 열에서의 실제 DO 농도는 $0.50 \mathrm{mg} / \mathrm{L} \sim 7.30 \mathrm{mg} / \mathrm{L}$ 로 운전되었고, 평균 $\mathrm{DO}$ 농도는 1 계열이 $4.10 \mathrm{mg} / \mathrm{L}, 2$ 계 열이 $3.01 \mathrm{mg} / \mathrm{L}$ 이다. 시스템 적용 이후 최적 $\mathrm{DO}$ 농 도는 평균 $1.79 \mathrm{mg} / \mathrm{L}, 1.04 \mathrm{mg} / \mathrm{L} \sim 3.50 \mathrm{mg} / \mathrm{L}$ 로 나타 났다. 3 월 17 일 이후에는 산정된 최적 $\mathrm{DO}$ 농도에 의 해서 송풍기를 제어 운전하였고, 시스템 적용 이전과
이후 비교 결과를 그래프로 나타내면 Fig.7 Fig.10 과 같다. 시스템 적용 후, 실제 DO 농도는 1 계열과 2 계열의 평균값이 $2.21 \mathrm{mg} / \mathrm{L}$ 와 $2.14 \mathrm{mg} / \mathrm{L}$ 로 $29 \% 46 \%$ 가량 낮아졌다. 유입공기량을 비교하여보면 시스템 적용 전이 $329 \mathrm{~m} 3 / \mathrm{hr} \sim 970 \mathrm{~m} 3 / \mathrm{hr}$ 인 반면 시스템 적 용 이후에는 $248 \mathrm{~m} 3 / \mathrm{hr} \sim 931 \mathrm{~m} 3 / \mathrm{hr}$, 평균 $558 \mathrm{~m} 3 / \mathrm{hr}$ 로 $17 \%$ 가량 적어졌으며, 전력량은 이와 거의 비례 하며, 시스템 적용 이전에는 $8.28 \mathrm{KW} \sim 24.89 \mathrm{KW}$ 였 으나, 시스템 적용 이후에는 $6.33 \mathrm{KW} \sim 24.62 \mathrm{KW}$, 평균 $14.20 \mathrm{KW}$ 로 마찬가지로 $17 \%$ 가량 적어진 것을 알 수 있다. 동일시기의 2013년 3월 17일 3월 31 일 데이터와 비교해 보면, 공기유입량은 평균 $731 \mathrm{~m} 3 / \mathrm{hr}$ 이고, 전력량이 평균 $16.18 \mathrm{KW}$ 로 시스템 적 용 전보다 높은 것을 알 수 있다. 반면, 방류수 COD 농도는 평균 $13.4 \mathrm{mg} / \mathrm{L}$ 에서 $13.7 \mathrm{mg} / \mathrm{L}$ 로, 방류수 T-N 농도는 평균 $17.1 \mathrm{mg} / \mathrm{L}$ 에서 $16.9 \mathrm{mg} / \mathrm{L}$ 로 다소 높아지 거나 낮아졌지만, 그 차이가 적으며 방류수질 기준을 넘지 않음을 알 수 있다.

즉, 기존의 높은 $\mathrm{DO}$ 농도는 미생물에게 필요 이상 의 공기가 공급되었다는 것을 알 수 있으며, 호흡률 을 이용한 최적 DO 농도 산정을 통한 송풍기 제어 운전으로 미생물이 활용 가능한 적정의 산소량을 포 기조에 공급할수 있었다. 위 기간 동안의 포기조 DO 농도는 기존 대비 약 $46 \%$ 로 낮아졌으며, 약 $17 \%$ 의 공기유입량이 적게 주입됨으로써 송풍기 가동을 위한 전력 비용을 감소시킨 것으로 나타났다.

\section{4. 결론}

본 연구에서는 하수처리장 내 포기조의 미생물 호 흡률을 측정함으로써, 미생물이 유기물 제거 및 질소 변환을 위해 필요한 적정 산소량을 계산하고, 포기조 


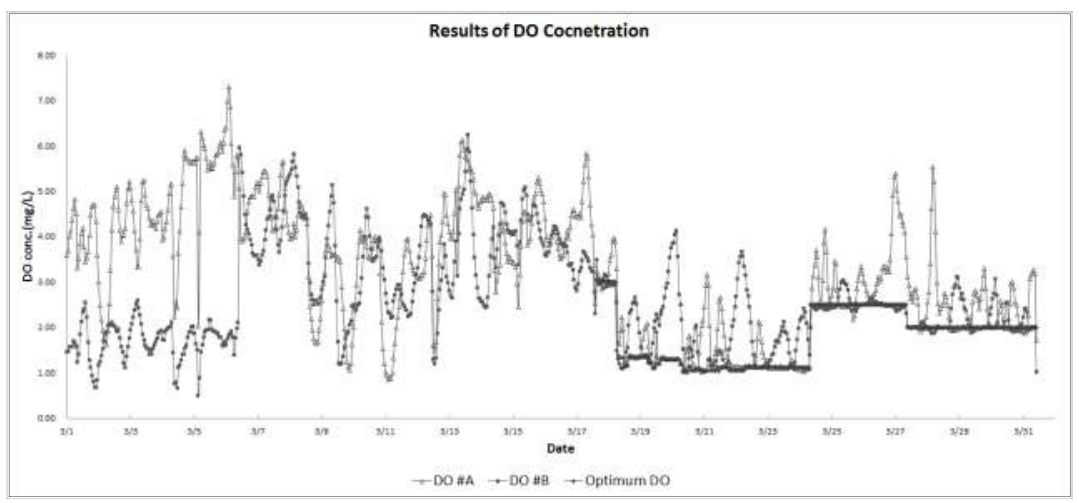

Fig. 7. The results of the DO concentration.

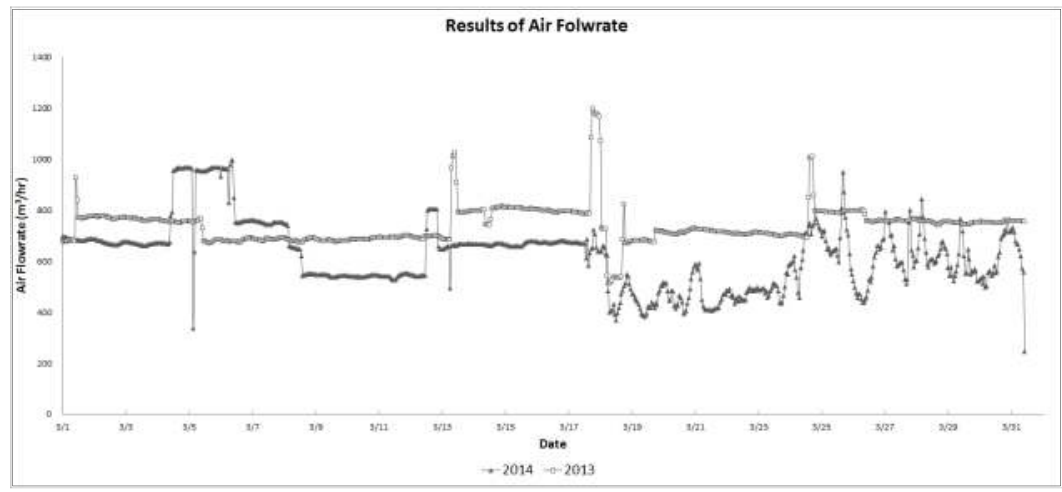

Fig. 8. The results of the air flowrate.

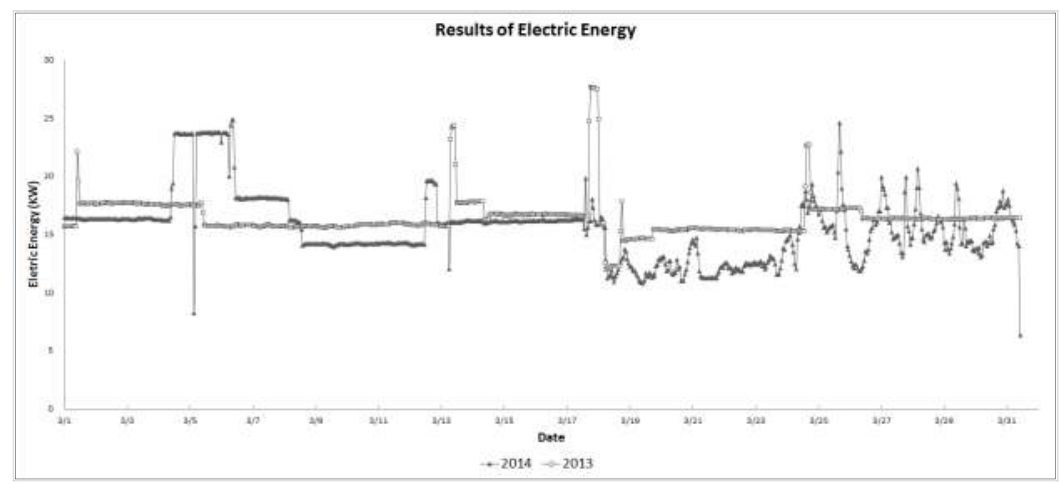

Fig. 9. The results of the electric energy.

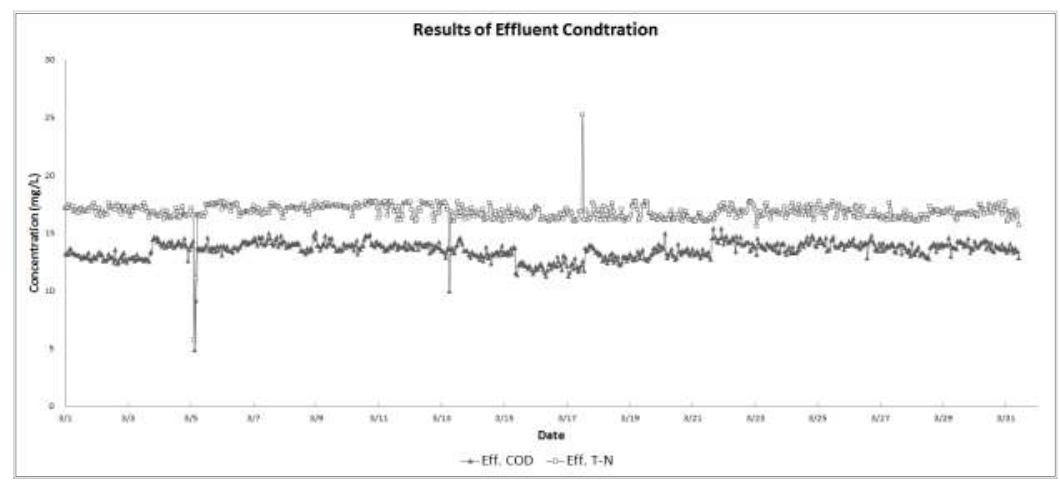

Fig. 10. The results of the effluent COD and T-N. 
의 최적 $\mathrm{DO}$ 농도를 산정하였다. 최적 $\mathrm{DO}$ 농도를 기 반으로 송풍기를 제어 운전한 결과, 방류 $\mathrm{COD}$ 및 T-N농도는 방류수질 기준 이하로 유지되면서, 시스 템 적용 전의 $\mathrm{DO}$ 농도에 비해 약 $46 \%$ 감소된 $\mathrm{DO}$ 농도 범위 운전됨과 동시에 약 $16 \%$, 시간당 평균 $2.63 \mathrm{KW}$ 의 전력량을 감소시켰다. 이는 한국전력에서 제시한 전기요금의 산업용전력(을) 고압A 선택ㅍㅎ형, 겨울철 최대부하 기준 155.5 원/KWH 적용하였을 경 우, 1 일 10,000 원, 1 년 360 만원 가량의 금액으로 환 산될 수 있다[16]. 이것은 기존 하수처리장 운영시 포 기조에 공기가 과량 공급되고 있었다는 것을 의미하 며, 최적 $\mathrm{DO}$ 산정 시스템을 적용한 결과 송풍기 전 력비용을 절감할 수 있을 것으로 판단된다.

본 연구내용은 복잡한 장비의 도입이나 특이한 알 고리즘을 사용하지 않으므로, 현장에 쉽게 적용가능 하며, 현재 방류수질에 기반한 최적 DO 농도 보정이 수행되므로, 계절에 관계없이 적용가능할 것으로 판 단된다. 하지만, 시스템이 적용된 기간이 매우 짧은 점과 또한 동절기 운전자료만 있다는 점이 한계점으 로 판단되며, 향후 장기간 제어운전을 통해 연구 내 용의 추가 검증하고자 한다.

$$
\text { 사 사 }
$$

이 논문은 글로벌탑환경기술개발사업(GT-11-B -01-109-0)의 지원을 받아 수행된 연구임.

\section{References}

1. 김병군, 이태호, 최광수, 김창원: "활성슬러지공 정 제어를 위한 부하율과 호흡률의 상관관계”, KSEE, vol. 18, no. 12, 1573 1582, (1996).

2. Henze, M., Gujer, W., Mino, T., Loosdrecht, M.: "Activated sludge models ASM1, ASM2, ASM2d and ASM3", IWA Scientific and Technical report No.9, IWA, UK, (1999).

3. Petersen, B.: "Calibration, identifiability and optimal experimental design of activated sludge models", Ph.D. thesis, BIOMATH, Gent UNIV., Belgium, (2001).

4. 김동한: "호흡률법에 의한 하수의 질산화성 질 소화합물 추정”, $\mathrm{KSWW}$, vol. 21, no. 3, 295 303, (2007).
5. 김민한: "Activated Sludge Model (ASM) 기반 유입수 성상 분석, 모델 보정, 최적화 그리고 하 수처리장 설계의 통합적 프로토콜 개발", 경희 대학교 석사학위논문, (2010).

6. 임정진: “활성슬러지모델 기반 유입수 성상분석, 모델 보정 및 최적화 연구”, 경희대학교 석사학 위논문, (2012).

7. 김동한, 김희준, 정태학: “호흡률법에 의한 하수 의 생분해 특성 평가: I. 호흡률법”, $\mathrm{KSWW}$, vol. 18, no. 1, 29 36, (2004)

8. Henze, M.: "Characterization of wastewater for modeling of activated sludge processes", WST, vol. 25, no. 6, 1 15, (1992).

9. Spanjers, H., Vanrolleghem, P.A.: "Respirometry as a tool for rapid characterization of wastewater and activated sludge", WST, vol. 31, no. 2, 105 114,(1995).

10. 신항식, 정형석, 남세용: “호흡률 측정법을 이 용한 슬러지내의 활성 미생물 농도 정량”, KSCE, vol. 21, no. 2, 165 170, (2001).

11. 정형석: “호흡률 측정법을 이용한 생물학적 질 소 제거공정의 모니터링과 시뮬레이션”, 한국 과학기술원 석사학위논문, (2000).

12. 이대성, 우승한: "생물학적 하폐수처리 공정에 서의 실시간 모니터링 센서", DICER Techinfo Part1, vol. 5, no. 5, 68 86, (2006).

13. 드림바이오스: "미생물활성도 측정장치(SRT -Meter)", (주)드림바이오스, 1 38, (2011).

14. 김민한, 유창규: “모델링 기법을 이용한 하폐수 처리 공정 설계와 환경성 및 경제성 평가", KICHE, vol. 46, no. 3, 610 618, (2008).

15. Zhou, Z., Wu, Z., Wang, Z., Tang, S., Gu, G., Wang, L., Wang, Y., Xin, Z.: "Simulation and performance evaluation of the anoxic/anaerobic/aerobic process for biological nutrient removal", KICHE, vol. 28, no. 5, 1233-1240, (2011).

16. httP://cyber.kepco.co.kr/ckepco/front/jsp/CY/E/ E/CYEEHP00101.jsp 